\title{
Variasi Suhu Terhadap Pertumbuhan Neisseria Gonorrhoeae Pada Media Coklat Agar Plate
}

\author{
Halimatussa'diah, Urip, Yunan Jiwintarum \\ Department of Health Analyst, Health Polytechnic of the Ministry of Health of Mataram, Indonesia \\ Email: halimatus.diah98@gmail.com
}

\begin{abstract}
ABSTRAK
Infeksi menular seksual (IMS) adalah infeksi yang penularannya terutama melalui hubungan seksual. Gonorrhoeae merupakan penyakit yang mempunyai insidens yang tinggi diantara Infeksi Penyakit Menular Seksual (PMS). Tujan dari penelitian ini adalah untuk mengetahui pengaruh variasi suhu terhadap pertmbuhan Neisseria gonorrhoeae. Penelitian ini bersifat pre eksperment dengan 6 perlakuan dan 4 replikasi yaitu pemanasan air dengan inokulasi lansung ke media, tanpa pemanasan, suhu $40^{\circ} \mathrm{C}, 50^{\circ} \mathrm{C}, 60^{\circ} \mathrm{C}$, dan $70^{\circ} \mathrm{C}$. Dilakuan peneletian dengan didapatkan hasil bahwa dari masing-masing perlakuan tidak terdapat pertumbuhan koloni pada media Coklat Agar Plate. Yang mengalami pertumbuhan hanya perlakuan dengan inokulasi lansung pada media Sehingga dapat disimpulkan bahwa tidak ada pengaruh variasi suhu pemanasan air terhadap pertumbuhan Neisseria gonorrhoeae pada media CAP.
\end{abstract}

Kata Kunci : Neisseria gonorrhoeae, Pertumbuhan, Suhu

\section{ABSTRACT}

Sexually transmitted infections (STI) are infections whose transmission is mainly through sexual intercourse. Gonorrhoeae is a disease that has a high incidence among sexually transmitted infections (STDs). The purpose of this study was to determine the effect of temperature variations on the growth of Neisseria gonorrhoeae. This study was pre-experimental with 6 treatments and 4 replications, namely heating water with direct inoculation to the media, without heating, temperature $40^{\circ} \mathrm{C}, 50^{\circ} \mathrm{C}, 60^{\circ} \mathrm{C}$, and $70^{\circ} \mathrm{C}$. It was examined by obtaining the results that from each treatment there was no colony growth on the Chocolate Agar Plate media. Those who experienced growth were only treated with direct inoculation on the media so that it could be concluded that there was no effect on the variation of water heating temperature on the growth of Neisseria gonorrhoeae on CAP media.

Keywords : Neisseria gonorrhoeae, Growth, Temperature

\section{Pendahuluan}

Infeksi Menular Seksual (IMS) disebut juga venereal (dari kata venus, yaitu Dewi Cinta dari Romawi kuno), didefinisikan sebagai salah satu akibat yang ditimbulkan karena aktivitas seksual yang tidak sehat sehingga menyebabkan munculnya penyakit menular (Masrizal, 2002). Terdapat lebih dari 30 jenis kuman berbeda yang diketahui ditularkan melalui kontak seksual. Infeksi yang paling sering ditemukan melalui infeksi menular seksual antara lain gonore, klamidiasis, trikomoniasis, herpes genitalis, infeksi Human Papilloma Virus (HPV), hepatitis B, dan sifilis, dan gonorrhoe (Pandjaitan et al., 2016).

Infeksi gonore di Indonesia menempati urutan yang tertinggi dari semua jenis PMS. Beberapa penelitian di Surabaya, Jakarta, dan Bandung terhadap WPS menunjukkan bahwa prevalensi gonore berkisar antara 7,4\%-50\% (Arifianti, Harbandinah, \& P, 2008).

Gonorrhoeae merupakan penyakit yang mempunyai insidens yang tinggi diantara Infeksi Penyakit Menular Seksual (PMS). Infeksi ini terjadi secara luas di seluruh dunia dengan prevalensi yang lebih tinggi di berbagai negara berkembang termasuk Indonesia(Pandjaitan et al., 2016).

Gonore (GO) didefinisikan sebagai infeksi bakteri yang disebabkan oleh kuman Neisseria gonorrhoea, suatu diplokokus gram negatif. Infeksi umumnya terjadi pada aktivitas seksual secara genito-genital, namun dapat juga kontak seksual secara oro-genital dan ano-genital. Pada laki-laki umumnya menyebabkan uretritis akut, sementara pada perempuan menyebabkan servisitis yang mungkin saja asimtomatik(Jawas \& Murtiastutik, 2006). 
Gonokokus termasuk golongan diplokokus berbentuk biji kopi dengan lebar $0,8 \mu$, panjang $1,6 \mu$ dan bersifat tahan asam. Kuman ini bersifat gram negatif, yang terlihat di luar atau di dalam sel polimorfonuklear (leukosit), tidak tahan lama di udara bebas, cepat mati pada keadaan kering, tidak tahan suhu di atas $39^{\circ} \mathrm{C}$ dan tidak tahan terhadap zat desinfektan. Afinitas kuman sangat baik pada mukosa yang dilapisi epitel silindris seperti pada vagina atau epitel lapis gepeng yang belum berkembang (imatur, pada wanita prepubertas) sedangkan epitel transisional dan berlapis pipih lebih resisten terhadap kuman gonokokus ini(Jawas \& Murtiastutik, 2006).

$$
\text { Karakteristik dari Neisseria }
$$
gonorrhoeae adalah meragikan karbohidrat, membentuk asam, tetapi tidak menghasilkan gas. N. gonorrhoeae menghasilkan oksidase dan memberi reaksi oksidase positif. Bakteri ini dengan cepat mati oleh pengeringan, sinar matahari, pemanasan basah, dan berbagai disinfektan. Bakteri ini menghasilkan enzim autolitik yang cepat mengakibatkan pembengkakan dan lisis in vitro pada suhu $25^{\circ} \mathrm{C}$ dan pada $\mathrm{pH}$ Basa(Dwi, 2011).

Pemeriksaan penunjang
memegang peranan penting dan
dilakukan adalah pering
pemeriksaan sediaan
langsung dengan membuat hapusan secret uretra atau serviks, dan biakan kuman. Dari pemeriksaan sediaan langsung yang dicat dengan Gram, akan tampak kuman diplokokus yang Gram negatif, berbentuk seperti ginjal pada intra selular atau ekstraselular. Sedangkan biakan kuman dengan menggunakan media Thayer-Martin memiliki sensitivitas dan spesifisitas yang tinggi (Daili 2001). Pada pengecatan Gram, Gonore dikatakan positif bila dijumpai adanya diplokokus gram negative dengan bentuk morfologinya yang khas dan biasanya terdentifikasi di dalam sel leukosit polimorfonuklear (intraselular) maupun dekat di sekitar sel leukosit (ekstraselular) (Gonore, Wanita, Sek, \& Di, 2012).

Pemeriksaan Gold Standart untuk Gonorhoeae adalah menggunakan kultur dengan media yang mengandung $\mathrm{CO}$, walaupun beberapa penelitian menunjukkan bahwa sensitifitas dan spesifisitas pemeriksaan menggunakan deteksi Nucleic Acid
Amplification Test (NAAT) atau Polymerasi Chain Reaction (PCR) lebih tinggi dibandingkan kultur (Gonore et al., 2012).

Neisseria gonorrhoeae bersifat fastidious dan untuk tumbuhnya perlu media yang lengkap serta baik. Akan tetapi, ia juga rentan terhadap kepanasan dan kekeringan sehingga tidak dapat bertahan hidup lama di luar hostnya( Ida Ayu Made Sri Arjani, n.d.). Neisseria gonorrhoeae tidak tahan lama di udara bebas, cepat mati pada keadaan kering, tidak tahan suhu di atas $39^{\circ} \mathrm{C}$ dan tidak tahan terhadap zat desinfektan (Jawas \& Murtiastutik, 2006).

Neisseria gonorrhoeae pada medium coklat agar plate harus diinkubasi $36^{\circ} \mathrm{C}$ selama 48 jam dengan $\mathrm{CO} 2(5-10 \%)$ (Koes Irianto, 2006). Neisseria gonorrhoeae untuk pertumbuhannya memerlukan media yang khusus karena sifatnya yang tidak tahan lama disuhu pemanaasan maka penulis tertarik untuk melakukan penelitian yang berjudul pengaruh variasi suhu terhadap pertumbuhan bakteri Neisseria gonorrhoeae pada media CAP.

\section{Metode Penelitian}

Penelitian ini besifat Pre Eksperiment yang dilakuan dilaboratorium untuk mengetahui suatu gejala atau pengaruh yang timbul sebagai akibat dari adanya perlakuan terhadap sampel(Notoadmojo,2010).

Dalam penelitian ini, peneliti ingin mengetahui pengaruh suhu terhadap pertumbuhan Neisseria gonorrhoeae pada media CAP dengan menggunakan 6 perlakuan yaitu :

$\mathrm{T} 0=$ Bakteri tanpa dilakukan perlakuan pemanasan

$\mathrm{T} 1=$ penambahan bakteri Neisseria gonorrhoeae pada $0^{\circ} \mathrm{C}$

$\mathrm{T} 2=$ Penambahan bakteri Neisseria gonorrhoeae pada suhu $40^{\circ} \mathrm{C}$

$\mathrm{T} 3=$ Penambahan bakteri Neisseria gonorrhoeae pada suhu $50^{\circ} \mathrm{C}$

$\mathrm{T} 4=$ Penambahan bakteri Neisseria gonorrhoeae pada suhu $60^{\circ} \mathrm{C}$

$\mathrm{T} 5=$ Penambahan bakteri Neisseria gonorrhoeae pada suhu $70^{\circ} \mathrm{C}$

Besar unit eksperimen dalam penelitian ini ditentukan dengan menggunakan rumus Federeer dalam buku kemas Hanafiah (2010) yaitu : 
1. Menentukan jumlah replikasi

$(\mathrm{t}-1)(\mathrm{r}-1) \geq 15$

$(6-1)(r-1) \geq 15$

$5(r-1) \geq 15$

$5 r-5 \geq 15$

$5 r \geq 15+5$

$5 r \geq 20 r \geq 20 / 5$

$r \geq 4$ replikasi

2. Menentukan unit jumlah percobaan

$=\quad 6 \times 4$

$=24$ unit percobaan

Keterangan:

$\mathrm{N}=$ Jumlah unit percobaan

$\mathrm{t}=$ Perlakuan

$r=$ Replikasi

\section{Pengurutan nomor}

Setiap unit percobaan diberi nomor urut $1-24$.

Data berupa pengaruh variasi suhu terhadap pertumbuhan Neisseria gonorrhoeae pada media CAP yang disajikan dalam bentuk tabel menggunakan uji deskriptif.

\section{Hasil Penelitian dan Pembahasan}

Hasil penelitian pengaruh suhu pemanasan air terhadap viabilitas Neisseria gonorrhoeae didapatkan hasil seperti terlihat pada tabel 4.1 .

Tabel 4.1. pertumbuhan Neisseria gonorrhoeae.

\begin{tabular}{|c|c|c|c|c|c|c|c|c|c|c|c|c|}
\hline \multirow{3}{*}{ Replikasi } & \multicolumn{12}{|c|}{ Pertumbuhan pada media CAP } \\
\hline & \multicolumn{2}{|c|}{ T0 } & \multicolumn{2}{|c|}{$\mathrm{T} 1$} & \multicolumn{2}{|c|}{$\mathrm{T} 2$} & \multicolumn{2}{|c|}{ T3 } & \multicolumn{2}{|c|}{ T4 } & \multicolumn{2}{|c|}{ T5 } \\
\hline & $\mathrm{t}$ & $\mathrm{tt}$ & $\mathrm{t}$ & $\mathrm{tt}$ & $\mathrm{t}$ & $\mathrm{tt}$ & $\mathrm{t}$ & $\mathrm{tt}$ & $\mathrm{t}$ & $\mathrm{tt}$ & $\mathrm{t}$ & $\mathrm{tt}$ \\
\hline 1 & $\sqrt{ }$ & & & $\sqrt{ }$ & & $\sqrt{ }$ & & $V$ & & $\sqrt{ }$ & & $\sqrt{ }$ \\
\hline 2 & $\sqrt{ }$ & & & $\sqrt{ }$ & & $\sqrt{ }$ & & $\sqrt{ }$ & & $\sqrt{ }$ & & $\sqrt{ }$ \\
\hline 3 & $\sqrt{ }$ & & & $\sqrt{ }$ & & $\sqrt{ }$ & & $\sqrt{ }$ & & $\sqrt{ }$ & & $\sqrt{ }$ \\
\hline 4 & $\sqrt{ }$ & & & $\sqrt{ }$ & & $\sqrt{ }$ & & $\sqrt{ }$ & & $\sqrt{ }$ & & $V$ \\
\hline
\end{tabular}

Neisseria ${ }^{--}$gonorrhoeae adalah organisme yang memerlukan kelembaban, $\mathrm{CO} 2$ yang tinggi, dan tumbuh pada media yang diperkaya agar coklat yang berisi darah(Aulia, 2017). Penularan Neisseria gonorrhoeae dengan inokulasi sekresi yang terinfeksi langsung dari satu mukosa ke mukosa lainnya (Magnus, 2012). Neisseria gonorrhoeae merupakan organisme peka yang tidak dapat bertahan lama diluar tubuh (Oktaviani, Ami, 2017).

Kemampuan bisa tumbuhnya bakteri Neisseria gonorrhoeae membutuhkan perlakuan yang khusus karena sifat dari bakteri tersebut yang fastidious (membutuhkan nutrisi dan lingkungan yang khusus) dan untuk tumbuhnya perlu media yang lengkap serta baik. Akan tetapi, ia juga rentan terhadap kepanasan dan kekeringan serta udara bebas sehingga tidak dapat bertahan hidup lama di luar host-nya. Penularan umumnya terjadi secara kontak seksual (IMS) dan masa inkubasi terjadi sekitar 2-5 hari (Gonore, Wanita, Sek, \& Di, 2012).

Cara penularan IMS adalah dengan cara kontak langsung yaitu kontak dengan eksudat infeksius dari lesi kulit atau selaput lendir pada saat melakukan hubungan seksual dengan pasangan yang telah tertular. Lesi bisa terlihat jelas ataupun tidak terlihat dengan jelas. Penularan hampir seluruhnya terjadi karena hubungan seksual (vaginal, oral, anal). Penularan IMS 
juga dapat terjadi dengan cara lain, melalui darah pada saat transfusi darah dengan darah yang sudah terinfeksi dan dari ibu kepada bayi pada saat hamil, saat melahirkan dan saat menyusui (Gonore, Wanita, Sek, \& Di, 2012).

Penelitian ini menggunakan air aquadest yang dipanaskan. Aquadest merupakan air hasil dari destilasi atau penyulingan, dapat disebut juga air murni (H2O). Karena H2O hampir tidak mengandung mineral. Sedangkan air mineral merupakan pelarut yang universal. Air tersebut dengan mudah menyerap atau melarutkan berbagai partikel yang ditemuinya dan dengan mudah menjadi terkontaminasi. Dalam siklusnya di dalam tanah, air terus bertemu dan melarutkan berbagai mineral anorganik, logam berat dan mikroorganisme(Santosa, 2012).

Penelitian ini dilakukan dengan pemanasan bakteri yang menggunakan suhu $0^{\circ} \mathrm{C}$ yang serta dilakukan percobaan menggunakan suhu $40^{\circ} \mathrm{C}, 50^{\circ} \mathrm{C}, 60^{\circ} \mathrm{C}$, dan $70^{\circ} \mathrm{C}$. Didapatkan hasil bahwa tidak terjadi pertumbuhan pada masing-masing media Coklat Agar Plate sehingga dapat dikatakan bahwa variasi suhu tidak berpengaruh terhadap pertumbuhan bakteri Neisseria gonorrhoeae pada media Coklat Agar Plate.

Hasil penelitian dari semua pemanasan menunjukkan hasil negatif, hal ini dapat disebabkan karena sifat bakteri Neisseria gonorrhoeae yang cepat mati secara in vitro jika berada di dalam media yang tidak cocok seperti aquadest, karena aquadest merupakan cairan yang hipertonik.

Media yang baik untuk pertumbuhan sel medium isotonis terhadap sel tersebut. Dalam larutan hipotonik air akan masukke dalam sel sehingga menyebabkan sel membengkak, sedangkan dalam larutan hipertonik air akan keluar dari sel sehingga membrane plasma mengerut dan lepas dari dinding sel (pasmolisis) (Haryanto, 2017). Oleh karena itu, bakteri Neisseria gonorrhoeae yang dipanaskan pada air aquadest mengalami kematian karena sifat aquadest yang hipertonik menyebabkan bakteri Neisseria gonorrhoeae mengalami lisis.

\section{Kesimpulan}

Dari hasil penelitian ini, dapat disimpulkan bahwa Bakteri Neisseria gonorrhoeae tumbuh pada media CAP (Coklat Agar Plate) yang tidak dilakukan perlakuan, akan tetapi Bakteri Neisseria gonorrhoeae tidak tumbuh dengan dilakukan perlakuan pemanasan pada suhu $0^{\circ} \mathrm{C}, 40^{\circ} \mathrm{C}, 50^{\circ} \mathrm{C}, 60^{\circ} \mathrm{C}$, dan $70^{\circ} \mathrm{C}$.

\section{Daftar Pustaka}

Arifianti, N. A., Harbandinah, P., \& P, P. N. (2008). Analisis Faktor-Faktor Penyebab Niat Wanita Pekerja Seks ( WPS ) Yang Menderita IMS Berperilaku Seks Aman ( Safe Sex ) Dalam Melayani Pelanggan. Promosi Kesehatan, 3(2), 102-114.

Aulia, R.H. (2012). Manifestasi Klinis Dan Diagnosa Laboratorium Infeksi Bakteri Neisseria gonorrhoeae. Borneo Lestari. Akademi Analis Kesehatan.

Dwi, A. (2011). Insidensi, karakteristik, dan Penata Laksanaan Penderita Gonore di Bagian Ilmu Kesehatan Kulit Dan Kelamin Fakultas Kedokteran 2011.

Haryanto, Yasmariel, Dini, (2017), Identifikasi Mikroba Pada Sample Susu Kedelai Dan Cimori Dengan Pewarnaan Gram, Universitas Sumatra Utara, Fakultas Tekhnik, Depertemen Teknik Kimia. Identifikasi agen penyebab infeksi menular seksual Ida Ayu Made Sri Arjani 1. (n.d.), 15-21.

James, G,C., Natalie, S. (2013). Manual Laboratorium Mikrobiologi Edisi 8. Buku kedokteran EGC. Indonesia. Jakarta.

Jawas, F. A., \& Murtiastutik, D. (2006). Penderita Gonore di Divisi Penyakit Menular Seksual Unit Rawat Jalan Ilmu Kesehatan Kulit dan Kelamin RSU Dr . Soetomo Surabaya Tahun 2002 - 2006 ( Gonorrhoeae Patients in Sexually Transmitted Diseases Division , Dermato Venereology Department of Dr . Soe, 2006, 217-228.

Jawetz., Melnick., Adelberg. (2007) Mikrobiologi kedokteran Edisi 23. Buku kedokteran EGC. Indonesia. Jakarta.

Jawetz., Melnick., Adelberg. (2010) Mikrobiologi kedokteran Edisi 25. Buku kedokteran EGC. Indonesia. Jakarta.

Masrizal. (2002). Faktor-faktor Yyang Berhubungan Dengan Tindakan Seks Komersial Dilokalisasi Teluju Pekanbaru, 5-12.

Nurdin, E., Bin, A., Abubakar, S., \& Malli, N. A. (2017). Jurnal Riset Kesehatan Gejala Klinis Infeksi Penyakit Menular Seksual Di Puskesmas Siko Kota Tenate Tahun 2016, 6(1), 50-53.

Nurhalina, A. (2012). Faktor faktor yang berhubungan dengan kejadian infeksi Gonore pada wanita penjaja sek komersial di 16 kabupaten/kota Indonesia.

Pandjaitan, M. C., Niode, N. J., Suling, P. L., Manado, S. R., Ilmu, B., Kulit, K., ... Manado, R. (2016). Gambaran Pengetahuan dan Sikap terhadap Infeksi Menular Seksual pada Remaja di SMA Frater Don Bosco Manado, (Cdc).

Santosa, B.A.,et.al. - Characteristics of extrudate from four varieties of corn with aquadest addition.\| Indonesian Journal of Agriculture 1.2 (2008):8594. 